\title{
A INFLUÊNCIA DAS REDES SOCIAIS NO PROCESSO ELEITORAL
}

Rodrigo Camargo Piva ${ }^{1}$

\section{Introdução}

A popularização das redes sociais ${ }^{2}$ é um fenômeno mundial e, ao que tudo indica, irreversível. No Brasil, o número de usuários aumentou exponencialmente nos últimos anos, acompanhando o processo de democratização da internet e a possibilidade de acesso à rede por meio de aparelhos celulares conhecidos como smartphones.

No Brasil existem, atualmente, quase 90 milhões de usuários do site de relacionamento Facebook, dos quais 59 milhões acessam a página diariamente. O número corresponde a oito de cada dez internautas, segundo a consultoria eMarketer ${ }^{3}$. Os dados são referentes ao segundo trimestre de 2014. Somente no último ano, o número de usuários na rede praticamente duplicou.

No que tange ao microblog Twitter, o país ocupa a segunda posição quanto ao número de usuários ativos (41 milhões), desbancando o Japão e ficando atrás, apenas, dos Estados Unidos.

A possibilidade de publicação instantânea de textos, imagens e conteúdo multimídia (áudio e vídeo) tornam as redes sociais o grande diferencial da comunicação deste século, superando, em muitos casos, a mídia convencional de rádio e TV, a qual se viu compelida a adaptar-se a essa nova dinâmica, sob pena de tornar-se completamente ultrapassada.

De outra parte, se expande a cada dia o uso da rede social como elemento catalisador de movimentos sociais e políticos, algo que ganha corpo justamente pelas dificuldades de controle ou censura no conteúdo veiculado pelos seus usuários.

Com efeito, foi justamente por meio das redes sociais que se articularam importantes revoltas populares, como a deposição do presidente egípcio Hosni Mubarak e do regime de quase meio século de Muamar Kadafi, na Líbia (movimento conhecido como "Primavera Árabe", que teve início em 2010, na Tunísia), além das passeatas e manifestações que levaram milhares de brasileiros às ruas, em 2013, protesto iniciado pelo Movimento Passe Livre (MPL), que exigia, a princípio, apenas a redução da tarifa de ônibus em algumas capitais brasileiras. 
Nas eleições gerais de 2014 no Brasil, observou-se, ainda, um outro fenômeno: a incorporação definitiva das mídias sociais na campanha eleitoral e a polarização na preferência do eleitorado, principalmente no segundo turno da eleição presidencial, a ponto de gerar sérios embates, discussões políticas e até mesmo troca de ofensas na rede.

\section{A internet como alternativa aos meios de comunicação tradicionais}

Pouco a pouco, os meios de comunicação de massa, como o rádio e a TV, vão perdendo terreno para a rede mundial de computadores. Percebe-se que até mesmo tradicionais veículos vão sendo substituídos, gradualmente, por sua versão eletrônica, a exemplo do Jornal do Brasil, do Rio de Janeiro, que, a partir de 2010, interrompeu a circulação de sua edição impressa.

Na verdade, é praticamente impossível competir com os recursos tecnológicos e o caráter dinâmico da internet, e as redes sociais, nesse aspecto, têm servido para difundir informações com uma velocidade espantosa. A par disso, na web é possível encontrar versões alternativas dos fatos, que diferem, muitas vezes da posição "oficial" adotada pelos meios de comunicação convencionais.

Para Marília Fattori,

Perdeu-se a fé nos veículos tradicionais pois, além da percepção de que o que era divulgado não correspondia à realidade, a informação era compartilhada entre os usuários, numa via de mão dupla, em que emissor e receptor do conteúdo se tratavam de pessoas comuns, ao contrário da comunicação estabelecida entre mídia tradicional e espectador. A comunicação nas redes sociais acontece de forma que as pessoas se sentem próximas, diferentemente do distanciamento criado pelos meios tradicionais, por se tratarem de corporações.

Assoma-se a isso o fato de que, através da internet, a comunicação ocorre de forma simples e instantânea, permitindo-se, inclusive, o anonimato. Assim, qualquer cidadão pode se transformar num jornalista ou comentarista amador, o que pode ser feito por meio de blogs e páginas pessoais, além dos já mencionados sites de relacionamento.

O fato é que o poder multiplicador das redes sociais supera qualquer outro tipo de mídia. Um usuário que tem, por exemplo, 1.000 amigos virtuais ou seguidores, ao fazer uma postagem no Facebook ou Twitter, em tese, tem 1.000 leitores em potencial, que, por sua vez, ao comparti- 
Iharem a mesma informação, vão produzindo o que se chama de "efeito viral", isto é, em poucas horas a notícia já chegou ao conhecimento de dezenas de milhares de pessoas, até que seja reproduzida, dependendo da sua relevância, pelos próprios meios de comunicação tradicionais.

\section{A propaganda eleitoral nas redes sociais}

Conforme dispõe o art. 57-A da Lei n. 9.504/1997 (Lei das Eleições), é permitida a propaganda eleitoral na internet após o dia 5 de julho do ano da eleição, a qual poderá ser realizada, entre outras formas, "por meio de blogs, redes sociais, sítios de mensagens instantâneas e assemelhados, cujo conteúdo seja gerado ou editado por candidatos, partidos ou coligações ou de iniciativa de qualquer pessoa natural" (inciso IV do mesmo artigo - grifamos).

Ressalte-se que tal dispositivo foi acrescentado à Lei das Eleições por meio da Lei n. 12.034/2009. Até então, não havia previsão sobre a forma de utilização de blogs e redes sociais para a veiculação de propaganda eleitoral, e a legislação eleitoral equiparava os provedores de internet às empresas de rádio e TV. ${ }^{4}$

Com a permissão do uso dos sites de relacionamento na campanha eleitoral, estes tornaram-se uma importante ferramenta à disposição dos partidos, candidatos e marqueteiros e, ainda, dos próprios eleitores na manifestação de sua preferência, haja vista as milhares de postagens de cunho político que invadiram o Twitter e o Facebook na recente disputa presidencial.

Ao tomar posse em 1.10.2013, o ministro do TSE João Otávio de Noronha assim se manifestou: "O mundo se comunica pelas redes sociais. $E$ nas eleições não poderia ser diferente. A modernidade chegou à campanha".

Nessa mesma linha, o TSE modificou o entendimento vigente na campanha eleitoral de 2010, isentando o Twitter das restrições que dizem respeito ao prazo formal da campanha. O novo entendimento majoritário é de que as mensagens do microblog "possuem caráter de conversa restrita aos seus usuários previamente aceitos entre si".

\section{A campanha virtual de 2014}

Sabedores do poder das mídias sociais, os partidos políticos organizam suas equipes de marketing digital para conquistar a máxima atenção do eleitorado. Tais equipes são encarregadas, também, de monitorar 
diariamente tudo que é publicado a respeito de seus candidatos, a fim de ajustar os rumos da campanha.

Seja através de suas fan pages (páginas criadas no Facebook sobre produtos, empresas ou celebridades, destinadas a reunir seguidores), seja por meio do Twitter, as redes sociais servem, também, como um canal direto de comunicação dos candidatos com o público em geral.

Diferentemente das campanhas anteriores, as eleições gerais de 2014 foram marcadas pelo forte engajamento dos internautas nas campanhas e por acaloradas discussões ideológicas, o que se amplificou com o acirramento da disputa presidencial entre os candidatos Dilma Rousseff, do PT, e Aécio Neves, do PSDB.

Nas semanas que antecederam à eleição em segundo turno, a divulgação de pesquisas que apontavam o empate técnico entre os dois candidatos à presidência deu ensejo a uma verdadeira batalha virtual nas redes sociais, com veementes declarações e pedidos de voto, denúncias, boatos e ofensas a ambos os concorrentes. As manifestações espontâneas e apaixonadas dos eleitores continuaram a ser veiculadas, inclusive, nos dias posteriores ao pleito.

Entre as publicações de maior alcance e repercussão, cabe destacar o perfil "fake" de grande sucesso chamado "Dilma Bolada", criado pelo publicitário carioca Jeferson Monteiro, no qual ele faz uma paródia da Presidente Dilma Rousseff, que hoje conta com mais de 1.600 .000 seguidores. De acordo com a descrição da página no Facebook, "Dilma Bolada" surgiu no Twitter, logo após o final das eleições presidenciais de 2010 e, segundo o próprio criador, trata-se de uma obra de ficção. Em setembro de 2013, Jeferson foi recebido pela própria presidente no Palácio do Planalto, encontro que marcou a volta dela ao Twitter.

\section{Boataria e ofensas na rede}

Tendo em vista que a maioria das restrições e prazos legais impostos à campanha eleitoral não se aplicam às redes sociais, conforme entendimento recente do TSE, tais canais de comunicação tiveram grande destaque no último pleito.

Todavia, a liberdade de expressão que rege o uso da internet no Brasil foi muitas vezes deturpada nas eleições 2014, com a veiculação de agravos e de notícias inverídicas a respeito de ambos os candidatos à presidência, causando, em muitos casos, prejuízos irreversíveis à imagem dos concorrentes e influindo, eventualmente, na opinião do eleitor. 
Na opinião de André Miranda,

Considerando-se, porém, o que se viu pela internet brasileira nos últimos meses, o pioneirismo francês em criar uma espécie de marketing político viral não apenas segue atual como marcou a eleição este ano no Brasil. Devido à facilidade de publicação e de capilaridade do meio, qualquer pessoa pôde se tornar um marqueteiro. Durante a campanha, todos os dias apareciam novas montagens de fotos favorecendo um candidato ou atacando o outro. Às vezes as imagens começavam a circular a partir dos perfis oficiais dos candidatos ou de seus partidos. Às vezes, elas vinham de meros militantes sem ligação partidária. E, em muitos casos, era impossível saber sua origem, o que facilitou que se propagassem mentiras e boatos.

Entre os boatos que circularam nas redes sociais na data da eleição para presidente (segundo turno), teve enorme repercussão a notícia de que o doleiro Alberto Youssef, um dos delatores do suposto esquema de corrupção na Petrobras, teria morrido naquele dia, vítima de envenenamento. Tal notícia causou grande furor e todo o tipo de especulações, entre elas que o "assassinato" teria ocorrido a mando do PT.

Ainda em relação a esse caso, a imagem da capa da Revista Veja, que circulou nas bancas na antevéspera da eleição, cuja reportagem afirmava que a presidente Dilma Rousseff e o ex-presidente Luiz Inácio Lula da Silva teriam conhecimento do esquema de corrupção da Petrobras, foi publicada e compartilhada inúmeras vezes em todas as redes sociais. Embora o TSE tenha concedido direito de resposta à coligação "Com a Força do Povo", da candidata Dilma Rousseff, e ao Partido dos Trabalhadores contra a Abril Comunicações S/A, pela veiculação de matéria supostamente difamatória, a decisão não impediu que centenas de usuários das redes sociais replicassem, no dia da eleição, a capa da revista.

O candidato do PSDB, Aécio Neves, também foi alvo de diversos boatos e especulações, como, por exemplo, as postagens que afirmavam que sua ex-mulher, Andrea, o acusava de ter usado a filha Gabriela, de 22 anos, para fazer contrabando internacional de diamantes, o que foi desmentido publicamente pela própria Andrea.

Outra postagem com eventuais efeitos deletérios e potencial para influir na opinião do eleitorado foi a imagem de um boletim de urna, publicada, na data da eleição, por um suposto mesário do município de Campina Grande, o qual alegava que a urna eletrônica de sua sessão já estava com 400 votos para a candidata Dilma Rousseff, antes mesmo de come- 
çar a votação. Nesse caso, foi comprovado tratar-se de uma fotomontagem, mas somente após a imagem ter sido compartilhada em todas as redes sociais durante o dia do pleito.

\section{A impossibilidade de controle sobre a internet}

A Lei 12.965, que estabelece princípios, garantias, direitos e deveres para o uso da internet no Brasil, conhecida como "Marco Civil", entrou em vigor há pouco tempo (junho/2014). Essa lei assegura, entre outras disposições, o princípio da neutralidade da rede, isto é, as empresas de telecomunicação não poderão filtrar ou bloquear o conteúdo das publicações, mantendo a neutralidade em relação ao fluxo de informação.

Segundo Leonardo Avritzer, professor da Universidade Federal de Minas Gerais (UFMG) e presidente da Associação Brasileira de Ciência Política,

O Brasil tem optado por hiper-regular a TV e não tem quase nenhuma regulação da internet. Na TV existe o exercício do direito de resposta. Se um candidato ataca outro, no dia seguinte o outro tem direito de resposta. Na internet, já temos o Marco Civil, que ajuda a tomar atitudes legais, mas a retirada do conteúdo é lenta. Numa eleição, se demorar 24 horas para tirar do ar pode ser muito tempo, porque a grande característica é o poder de replicar rapidamente uma mensagem - analisa Avritzer.

A seu turno, o STJ (Superior Tribunal de Justiça) já decidiu que os provedores de internet não são obrigados a indenizar usuários prejudicados pela veiculação de conteúdo na rede. Isso não impede que empresas como o Google e o Facebook sejam intimadas, judicialmente, a retirar do ar eventual conteúdo ofensivo ou difamatório. Entretanto, a responsabilidade civil da empresa vai depender, obviamente, de sua conduta, se omissiva ou não. ${ }^{5}$

Na prática, verifica-se que o fluxo de informações na web é praticamente impossível de ser controlado ou submetido a censura prévia, mais ainda com as novas tecnologias disponíveis, que permitem não apenas a divulgação instantânea de qualquer conteúdo - seja por meio de sites, blogs ou redes sociais, por intermédio dos incontáveis provedores de internet existentes no Brasil e no mundo -, mas também o compartilhamento das informações por milhares de internautas, provocando o já mencionado "efeito viral". Dessa forma, mesmo que o provedor cumpra a decisão de excluir da rede determinado conteúdo considerado ofensivo (o que nem sempre ocorre com a agilidade necessária), é prová- 
vel que até esse momento o material (texto, imagem ou vídeo) já tenha sido copiado, reproduzido e compartilhado em outros locais da rede. Ou seja: tira-se daqui, põe-se ali.

Ademais, se a ofensa for veiculada na véspera ou no dia da eleição, os efeitos danosos de uma publicação desse tipo dificilmente poderão ser reparados, e não há como ser avaliada a extensão do prejuízo à imagem de um candidato que foi alvo de ofensa, difamação ou notícia inverídica no momento crucial que antecede a votação.

\section{Considerações finais}

Infelizmente, a evolução da humanidade, nos planos ético, moral e ecológico, não tem acompanhado com a mesma rapidez os avanços tecnológicos e o desenvolvimento de novos recursos para a difusão de informações na sociedade contemporânea.

Se, por um lado, a internet revolucionou costumes e encurtou distâncias, além de ser uma fonte inesgotável de pesquisa, percebe-se que o seu uso pode ser facilmente desvirtuado, conforme se viu nas eleições de 2014.

O problema, portanto, não é a ferramenta, mas o uso que se faz dela.

O incentivo aos crimes de ódio nas redes sociais, tais como as publicações com conteúdo discriminatório aos nordestinos, por terem demonstrado preferência a um candidato à presidência ao invés de outro, só pode ser profundamente lamentado, servindo de reflexão sobre a importância do investimento na educação e na conscientização política de um povo.

Paralelamente, poderia se pensar que os sites de relacionamento estimularam o intercâmbio de ideias e uma maior participação popular na campanha eleitoral, sempre que isso tenha sido feito de forma cordial e respeitosa, o que nem sempre ocorreu.

Não há como mensurar, por fim, a intensidade com que a discussão política na internet, assim como a disseminação de boatos, injúrias e inverdades possam ter influído na vontade do eleitor, a ponto de modificar a escolha de seus candidatos. ${ }^{6}$

Como já se viu, a imensa popularização da internet e, por conseguinte, das redes sociais, é um fenômeno a ser estudado e amadurecido pelos ramos especializados do Direito e da Sociologia, assim como as formas de regulamentação do seu uso, ainda incipientes no Brasil e no mundo. 


\section{Referências}

DUARTE, Letícia. Como as redes sociais vão interferir na próxima eleição? Jornal Zero Hora. Disponível em http://zh.clicrbs.com.br/rs/noticias/proa/noticia/2014/07/como-as-redes-sociais-vao-interferir-na-proxima-eleicao4554663.html. Acesso em 6.11.2014.

FATTORI, Marília. Protestos e Manifestações: Redes Sociais X Mídias Tradicionais. Disponível em http://www.dp6.com.br/protestos-e-manifestacoes-redessociais-X-midias-tradicionais/. Acesso em 6.11.2014.

KIOSKEA.NET. Twitter atinge o meio milhão de usuários: o Brasil chega na segunda posição. Disponível em http://pt.kioskea.net/faq/12500-twitter-atinge-o-meio-milhao-de-usuarios-o-brasil-chega-na-segunda-posicao. Acesso em 7.11.2014.

LIMA, Maria. Aécio reage a envolvimento de sua filha ex-mulher em boatos nas redes sociais. Jornal O Globo. Disponível em http://oglobo.globo.com/ brasil/aecio-reage-envolvimento-de-sua-filha-ex-mulher-em-boatos-nas-redes-sociais-13113008. Acesso em 6.11.2014.

MIRANDA, André. Eleição foi marcada por guerra de marketing viral. Jornal O Globo. Disponível em http://oglobo.globo.com/brasil/eleicao-foi-marcada-porguerra-de-marketing-viral-14371783. Acesso em 10.11.2014.

TSE. Notícias 2013. TSE decide que manifestação política pelo Twitter não configura propaganda eleitoral. Disponível em http://www.tse.jus.br/noticiastse/2013/Setembro/tse-decide-que-debate-politico-pelo-twitter-nao-configurapropaganda-eleitoral. Acesso em 6.11.2014.

VEJA. São Paulo: Abril, ed. 2397, n. 44, 23 out. 2014.

\section{Notas}

${ }^{1}$ Bacharel em Direito pela UFRGS. Analista Judiciário e Chefe da Seção de Publicações Técnico-Eleitorais do Tribunal Regional Eleitoral de Santa Catarina. Especialista em Psicologia Transpessoal. Cantor e compositor de MPB (www.rodrigopiva.com.br / piva@tre-sc.gov.br).

${ }^{2}$ Além do Facebook e do Twitter, também são utilizadas no Brasil outras redes sociais, tais como o Linkedin, o Google+ e o próprio Youtube - site de compartilhamento de vídeos que permite a interação entre os usuários por meio de comentários. Todavia, o presente trabalho se concentrou na análise das duas primeiras, que são as mais populares no país.

${ }^{3}$ Informações fornecidas pelo site PROXXIMA. Disponível em http:// www.proxxima.com.br/home/social/2014/08/22/No-Brasil-Facebook-tem-89milh-es-de-usu-rios-mensais-ativos.html. Acesso em 6.11.2014. 
${ }^{4}$ De acordo com a Resolução TSE n. 22.718, que regulamenta as eleições 2008, a propaganda eleitoral na internet era permitida apenas na página do candidato destinada especificamente à campanha (com a terminação "can"), proibindo, ainda, a divulgação de informações que pudessem caracterizar o uso de propaganda favorável ou contrária a um candidato.

5 STJ, 3a. Turma, REsp 1193764-SP, rel. Min. Nancy Andrighi, ac. un., j. 14.12.2010.

${ }^{6}$ Segundo pesquisa realizada pelo Instituto MDA, encomendada pela Confederação Nacional do Transporte, as informações veiculadas sobre política poderiam modificar o voto de $26,5 \%$ dos entrevistados, não obstante o baixo percentual de pessoas que confiam nas informações disponibilizadas nesses canais (23,5\%). Disponível em http://www.ebc.com.br/eleicoes-2014/ galeria/videos/2014/08/mais-26-podem-mudar-o-voto-por-causa-deinformacoes-nas-redes. Acesso em 10.11.2014. 